\title{
Determining key performance indicators for warehouse performance measurement - a case study in construction materials warehouse
}

\author{
Elisa Kusrini*, Fadrizal Novendri, and Vembri Noor Helia \\ Department of Industrial Engineering, Universitas Islam Indonesia, Jl.Kaliurang km 14.5, Yogyakarta, Indonesia
}

\begin{abstract}
Warehouse performance measurement is needed to improve performance of logistics system. In order to improve warehouse performance, it is necessary to identify Key Performance Indicator (KPI). Different warehouses have different KPI, therefore this research aims to identify the most important KPI of warehouse so that warehouse manager can determine corrective actions in their warehouse efficiently and effectively. In this research, 25 KPI of warehouse are identified in five warehouse activities based on Frazelle model. The most important KPI are then determined in each warehouse activity using Analytical Hierarchy Process (AHP). Warehouse performance are measured and final score is determined using SNORM. Improvement steps are proposed base on benchmarking among warehouses. Warehouse performance measurement is conducted in 5 construction's material warehouses located in Yogyakarta, Indonesia. From this study, it is found that most important KPI for receiving is productivity (receive per man-hour), KPI for put away is cycle time (put away cycle time), KPI for storage is utilization (\% location and cube occupied), KPI for order picking is cycle time (order picking cycle time) and KPI for shipping is productivity (order prepared for shipment per man-hour). Improving warehouse performance could be done by comparing warehouse performance with the best performance among peer group.
\end{abstract}

\section{Introduction}

The increasingly competition requires company to improve their logistics performance. One of the important component in logistic performance is warehouse performance. Good warehouse performance will improve quality performance, delivery time, customer satisfaction and reduce cost in logistics system [1]. Warehouses are dedicated space for storage and handling of materials. In supply driven chain, warehouses hold stocks to feed internal department such as manufacturing and production. In demand-driven chain, warehouses store goods to fulfill the needs of external customers [2].

Due to the increasing complexity of logistic network, the warehouse performance analysis has become an important issue [3]. Warehouse performance evaluation has been studied in different ways by many researchers. Each focuses on different studies, in term of objectives, indicators, warehouse systems, measuring instruments etc. Regarding all this diversity, there is not a consensus of a group of measures used to assess warehouse performance [4]. Different types of warehouse require different indicators/metric. Therefore, this research aims to identify the most importance key performance indicators for warehouse in order to help warehouse manager to improve warehouse performance effectively. This paper studies warehouse performance measurement on five different construction material warehouse located in Yogyakarta, Indonesia.

\section{Literature Review}

\subsection{Warehouse Activities}

In general, warehouse activity consists of receiving, put away, storage, picking and shipping [5] Receiving is operation that involve the assignment of trucks to dock and the scheduling and execution of unloading Activities [6]. Put away is activity of placing a product or material that has been purchased in the warehouse. This activity including material handling activities verifying the location of the product material and the placement of the product [5]. Storage is movement of material from unloading area to its designated place [7]. Order Picking is order preparation. It is regarded as the main and laborintensive activity of warehouses [8, 9]. Shipping is activity that involves scheduling and assignment of trucks to docks the orders, packing after picking and the loading of trucks [6]. Warehouse activity based on Frazelle model [5] is depicted in Figure 1.

\footnotetext{
*Corresponding author: elisa_kusrini@uii.ac.id
} 


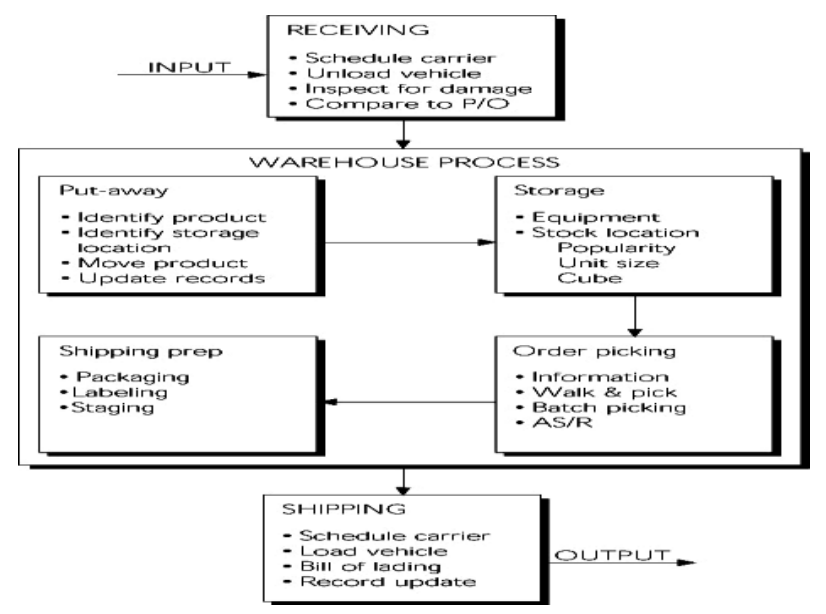

Fig.1. Warehouse activity [5]

\subsection{Warehouse Performance Measurement}

A warehouse performance measurement is a method to measure activity performance, program or service which is provided by a warehouse. Performance measurement system as the sets of metric used to quantify both the efficiency and effectiveness of action [10]. Performance measurement can be divided in 4 categories: input, output, efficiency and effectiveness [11]. In general, efficiency and effectiveness is the most widely utilized as a measure of performance $[11,12]$.

There are many methods for classifying warehouse performance measures. Performance warehouse based on traditional logistics performance measures include 'hard' and' soft' metrics. The first one treats quantitative measures such as order cycle time, fill rates and costs; the second deals with qualitative measures like the manager's perceptions of customer satisfaction and loyalty [13]. [14] distinguishes over direct and indirect indicators, where hard indices as indirect indicators. Different classifications are given by [15] that classify the performance of the warehouse into 130 indicators. In line with traditional logistic performance and direct performance, Frezelle model classify performance measured into 25 KPIs throughout the warehouse activity, i.e. financial, productivity, utilization, quality and cycle time.

Until recently, there is no agreement among researcher which KPI suitable for warehouse. Therefore, this study aims to identify the KPI on warehouse, especially for construction material's warehouse. In this research, we will measure hard or direct indicator using Frazelle model because it is in line with measure proposed by previous researcher and considered relevant for construction material warehouse. According to Frazelle model, warehouse key performance indicator (KPI) is shown in Figure 2.

\section{Warehouse Performance Measurement in Construction Materials Warehouse}

In this study, performance measurement is conducted in five warehouses that store construction materials such as brick, paving blocks, piles and concrete electric poles.
This warehouse is owned by small medium's construction company in Yogyakarta, Indonesia. It is done in 3 steps as follows.

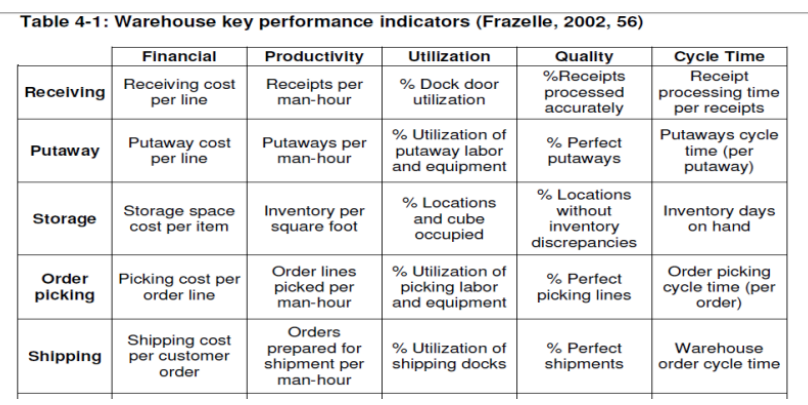

Fig.2.Warehouse Key Performance Indicators [5]

Step 1. Identifying importance weight of KPI. A questionnaires of pair wise comparisons among indicators (KPIs) is prepared and a total of five senior manager of construction materials warehouse were asked to give their preferences on the questionnaires. The scale of 1 to 9 (1 = equally, $3=$ moderate, $5=$ strong, $7=$ very strong, $9=$ extreme) is utilized to rate the preferences of the expert. Consistency Ratio (CR) is used to check the consistency of the comparison. CR less than 0.1 means that comparison is accepted. The results of questionnaires is analyzed using Analytical Hierarchy Process (AHP) model. Analytical Hierarchy Process was first introduced by Thomas L. Saaty in 1971 and became the most widely method for Multiple Criteria Decision Making (MCDM). It is a decision-making approach that is designed to find solutions to complex problems with multiple criteria into multiple domains. It is also known as an essential tool for practitioners and academics to conduct research in decision making and measure management theory. Analytic Hierarchy Process as a flexible problem-solving methods [16]. The result of importance weight of each KPIs can be seen in Table 1.

Table 1. The importance weight of each warehouse KPIs

\begin{tabular}{|l|l|l|l|l|l|}
\hline Activity & $\begin{array}{c}\text { Finan- } \\
\text { cial }\end{array}$ & $\begin{array}{c}\text { Produc- } \\
\text { tivity }\end{array}$ & $\begin{array}{c}\text { Utili- } \\
\text { zation }\end{array}$ & Quality & $\begin{array}{c}\text { Cycle } \\
\text { time }\end{array}$ \\
\hline Receiving & 0,19 & $\mathbf{0 , 4 1}$ & 0,08 & 0,16 & 0,17 \\
\hline Put Away & 0,12 & 0,23 & 0,19 & 0,14 & $\mathbf{0 , 3 2}$ \\
\hline Storage & 0,15 & 0,17 & $\mathbf{0 , 3 4}$ & 0,20 & 0,13 \\
\hline $\begin{array}{l}\text { Order } \\
\text { picking }\end{array}$ & 0,16 & 0,18 & 0,15 & 0,20 & $\mathbf{0 , 3 1}$ \\
\hline Shipping & 0,14 & $\mathbf{0 , 3 0}$ & 0,16 & 0,24 & 0,15 \\
\hline
\end{tabular}

Step 2. Determining the most important KPI for warehouse. It is carried out by selecting the highest weight among KPI on each warehouse activity. KPI with the highest weight regarded as the most important KPI. KPI for receiving is productivity (Receipt per man-hour), KPI for put away is cycle time (put away cycle time), KPI for storage is utilization (\% location and cube occupied), KPI for order picking is cycle time (order picking cycle time) and KPI for shipping is productivity (order prepared for shipment per man-hour).

Step 3. Measuring warehouse performance using selected KPIs. Warehouse performance is measured using selected KPIs and then scored them using standardized 
method, i.e SNORM based on benchmark data among warehouses. The process of normalization (SNORM) De Boer [17] employed scale of 0 to 100 to get the value of each metric with the following formula:

Larger is better

$$
\text { Snorm }=((\text { Si-SMin }) /(\text { Smax }- \text { SMin })) \times 100
$$

Lower is better

$$
\text { Snorm }=((\text { SMax-Si }) /(\text { SMax-Smin })) \times 100
$$

where,

$\mathrm{Si}=$ average value

$\mathrm{S} \max =$ the value of achieving the best performance indicators

$\mathrm{S} \min =$ the value of achieving the worst performance indicators

The performance of each warehouse presented in Table 2. Final score of warehouse performance is average of each score of warehouse activity as presented in Table 3.

Base on the result, improvement of warehouse performance could be executed through benchmarking based on the final score of each warehouse. Benchmarking is a measure for improving performance by learning from best practices and understanding the processes by which they are achieved [18]. There are 7 types of benchmarking, one of them is called process benchmarking. Process benchmarking is used when the focus is on improving specific critical processes and operations by learning from best practice organizations that perform similar work or deliver similar services [19]. Therefore, in this study, process benchmarking is employed by comparing each warehouse performance activity/operation with the best activity performance among peer group.

Referring to the warehouse score as presented in Table 2 , warehouse 1 has the best performance on the activity of put away, storage and order picking. While warehouse 3 has the best performance in receiving activity. Warehouse 5 is the best warehouse on shipping activity. This result can be used by the warehouse manager to improve its performance by referring to the best warehouse performance. The highest performance on each activity could be a target setting for other warehouses in order to improve their performance. The advantage of process benchmark in this study is simple and easy to do. However, it is only useful for the short term improvement, not for long term. A more advanced benchmarking method is using mathematical model such as Data Envelopment analysis (DEA) which is a tool for the evaluation of the performance of an activity within a unit of entities or organizations [20]. DEA is a mathematical model by calculating the efficiency level and can be used for benchmarking with clear and objective methodologies [21]. This can be an opportunity for further research.

\begin{tabular}{|c|c|c|c|c|c|}
\hline KPIs & WH 1 & WH 2 & WH 3 & WH 4 & WH 5 \\
\hline $\begin{array}{c}\text { Receipt per } \\
\text { man-hour } \\
\text { (unit/hour) }\end{array}$ & 5,56 & 187,5 & 945 & 187,5 & 333 \\
\hline $\begin{array}{l}\text { Put away } \\
\text { cycle time } \\
\text { (unit/hour) }\end{array}$ & 1,52 & 3 & 2,5 & 2 & 10 \\
\hline $\begin{array}{c}\% \text { location } \\
\text { and cube } \\
\text { occupied }(\%)\end{array}$ & 75 & 60 & 65 & 43,33 & 46,2 \\
\hline $\begin{array}{c}\text { Order picking } \\
\text { cycle time } \\
\text { (unit/order) } \\
\end{array}$ & 0,5 & 3 & 1,5 & 1 & 28 \\
\hline $\begin{array}{c}\text { Order } \\
\text { prepared for } \\
\text { shipment per } \\
\text { man-hour } \\
\text { (unit/hour) } \\
\end{array}$ & 6,44 & 9,3 & 187,5 & 162,5 & 226 \\
\hline $\begin{array}{l}\text { Receipt per } \\
\text { man-hour } \\
\text { (unit/hour) }\end{array}$ & 5,56 & 187,5 & 945 & 187,5 & 333 \\
\hline $\begin{array}{l}\text { Put away } \\
\text { cycle time } \\
\text { (unit/hour) }\end{array}$ & 1,52 & 3 & 2,5 & 2 & 10 \\
\hline $\begin{array}{c}\% \text { location } \\
\text { and cube } \\
\text { occupied }(\%)\end{array}$ & 75 & 60 & 65 & 43,33 & 46,2 \\
\hline $\begin{array}{c}\text { Order picking } \\
\text { cycle time } \\
\text { (unit/order) } \\
\end{array}$ & 0,5 & 3 & 1,5 & 1 & 28 \\
\hline $\begin{array}{c}\text { Order } \\
\text { prepared for } \\
\text { shipment per } \\
\text { man-hour } \\
\text { (unit/hour) }\end{array}$ & 6,44 & 9,3 & 187,5 & 162,5 & 226 \\
\hline
\end{tabular}

Table 2. Warehouse performance

Table 3. Performance score using SNORM

\begin{tabular}{|l|c|c|c|c|c|}
\hline \multicolumn{1}{|c|}{ KPI } & WH 1 & WH 2 & WH 3 & WH 4 & WH 5 \\
\hline $\begin{array}{l}\text { Receipt per } \\
\text { man-hour } \\
\text { (unit/hour) }\end{array}$ & 0 & 19.04 & 100 & 19.04 & 34.08 .00 \\
\hline $\begin{array}{l}\text { Put away } \\
\text { cycle time } \\
\text { (unit/hour) }\end{array}$ & 100 & 64.06 .00 & 88.04 .00 & 94.03 .00 & 0 \\
\hline $\begin{array}{l}\text { \% location } \\
\text { and cube } \\
\text { occupied } \\
\text { (\%) }\end{array}$ & 100 & 52.06 .00 & 68.04 .00 & 0 & 09.01 \\
\hline $\begin{array}{l}\text { Order } \\
\text { picking } \\
\text { cycle time } \\
\text { (unit/order) }\end{array}$ & 100 & 89.01 .00 & 96.04 .00 & 98.02 .00 & 0 \\
\hline $\begin{array}{l}\text { Order } \\
\text { prepared } \\
\text { for shipment } \\
\text { per man- } \\
\text { hour } \\
\text { (unit/hour) }\end{array}$ & 0 & 01.03 & 82.05 .00 & 71.01 .00 & 100 \\
\hline $\begin{array}{l}\text { Average } \\
\text { Score }\end{array}$ & 60 & 45.04 .00 & 87.01 .00 & 56.06 .00 & 28.08 .00 \\
\hline
\end{tabular}




\section{Conclusion}

Warehouse activity improvement can be done based on the most important KPI in each activity. This is to facilitate warehouse managers in determining strategies and actions to improve warehouse performance. From this research, it is found that the most important KPI for receiving is productivity (receive per man-hour), KPI for put away is cycle time (put away cycle time), KPI for storage is utilization (\% location and cube occupied), KPI for order picking is cycle time (order picking cycle time) and KPI for shipping is productivity (order prepared for shipment per man-hour).Based on the KPI's score, warehouse performance improvement can be done through process benchmarking. Although this research is focused on measuring performance in construction materials warehouse, the result and methodology can be employed for other type of warehouses. Further research is to improve warehouse performance through benchmarking using mathematical methods, such as Data Envelopment Analysis.

\section{References}

1. A. D. Marco and G. Mangano, Relationship between logistic service and maintenance costs of warehouses. Facilities Emerald Group Publishing Limited, Vol. 29 No. 9/10, pp. 411-421 (2011)

2. S. Emmet, Excellence in Warehouse Management. John Wiley and Sons Ltd, West Sussex (2005)

3. $\mathrm{Y}$. $\mathrm{Wu}$, and M.Dong, Combining multi-class queueing networks and inventory models for performance analysis of multiproduct manufacturing logistics chains. The International Journal of Advanced Manufacturing Technology, 37 (5-6): 564-575 (2007)

4. J.S. Keebler, and R.E. Plank, Logistics performance measurement in the supply chain: a benchmark. Benchmarking: An International Journal 16 (6):785798 (2009)

5. E. H. Frazelle, World-Class Warehousing and Material Handling. McGraw-Hill Book Company(2002)

6. J.X. Gu, M. Goetschalckx, and L.F. McGinnis, Research on warehouse operation: a comprehensive review. European Journal of Operational Research 177 (1): 1-21 (2007)

7. A. Johnson, and L. Mcginnis, Performance measurement in the warehousing industry, IIE Transactions (2011) 43, 220-230 (2011)

8. M. Dotoli, M.P. Fanti, G. Iacobellis, G. Stecco, and W. Ukovich, Performance analysis and management of an automated distribution center. 35th Annual Conference of IEEE Industrial Electronics, November 4371-4376 (2009)

9. E.H. Grosse, C.H.G. Carlo, and K. Giersch. An experimental investigation of learning effects in order picking systems. Journal of Manufacturing
Technology Management Vol. 24 No. 6, pp. 850872(2013)

10. A.Neely, M.Gregory, and K. Platts, Performance measurement system design: a literature review and research agenda, International Journal of Operation and Production Management, Vol 25, (2005) 1228 1263 (2005)

11. D.N. Ammons, Overcoming the inadequacies of performance measurement in local government: the case of libraries and leisure services. Public Administration Review, 55(1) 37-47( 1995)

12. E. Kusrini, Subagyo, and N.A. Masruroh, Good criteria for supply chain performance measurement. International Journal of Engineering Business Management, 6:9. doi: 10.5772/58435 (2014)

13. G. Chow, T.D. Heaver, and L.E. Henriksson, Logistics Performance: Definition and Measurement. International Journal of Physical Distribution \& Logistics Management 24 (1): 17-28 (1994)

14. F.H. Staudt, G. Alpan, M. Mascol, C.M.T.Rodriguez, Warehouse performance measurement: a literature review. International Journal of Production Research, Vol. 53, No. 18, 5524-5544 (2015)

15. E. Krauth, H. Moonen, V. Popova, and M. Schut, Performance indicators in logistics service provision and warehouse management - a literature review and framework, on-line at http://www.cs.vu.nl/ schut/pubs/mcsKrauth2005a.pdf (2005)

16. T.L. Saaty, The analytic hierarchy and analytic network measurenment process: application to decisions under risk. European Journal of Pure and Applied Mathematics1(1) 122-96 (2008)

17. J.H. Trienekens, and H.H. Hvolby, Performance measurement and improvement in supply chain, Proceeding on the third CINET Conference, CI 2000 from Improvement to Inovation, Aalborg (2000)

18. R.E. Mittelstaedt, Robert E, Jr, Benchmarking: How To Learn from Best-In-Class Practices, National Productivity Review (1986-1998), 11, 3; ABI/INFORM Collection, pg. 301 (1992)

19. M. Isoraite, Theoretical Aspects of Benchmarking Theory, vieðoji politika ir administravimas, ISSN 1648-2603 (2004)

20. A. Charnes, W.Cooper, and E. Rhodes, Measuring the efficiency of decision making units. European Journal of Operational Research, Vol. 2 No. 6, 429444 (1978)

21. Coelli, T., A Guide to DEAP version 2.1. A Data Envelopment Analysis (Computer) Program, Departement of Economic University of New England (1996) 